\title{
Not all long-distance-exploration types of ectomycorrhizae are the same: differential accumulation of nitrogen and carbon in Scleroderma and Xerocomus in response to variations in soil fertility
}

\author{
Lidia K Trocha ${ }^{(1)}$, \\ Bartosz Bułaj (2), \\ Anna Durska ${ }^{(1)}$, \\ Marcin Frankowski ${ }^{(3)}$, \\ Joanna Mucha ${ }^{(4)}$
}

\begin{abstract}
Long-distance-exploration type (LDET) ectomycorrhizae have been reported to be best adapted to infertile soils, but variation within LDET ectomycorrhizae have not been thoroughly examined. Concentrations of nitrogen $(\mathrm{N})$ and carbon $(C)$ in LDET ectomycorrhizae were examined in Xerocomus-Pinus sylvestris and Scleroderma-Quercus petraea ectomycorrhizae. The study determined how concentrations of these elements vary in ectomycorrhizae in fertile (organic, uppermost mineral) and infertile (brunic) soil layers. The organic horizon in both Scots pine and sessile oak forest soils had the highest mineral status and exchange cations. In contrast, low mineral concentrations, high base saturation, and $\mathrm{pH}$ were characteristic of the brunic horizon in both forest stands. Xerocomus ectomycorrhizae had a higher concentration of $\mathrm{N}$ in the fertile (organic and uppermost mineral) soil horizons (3.4\%) than in the infertile (brunic) soil horizon (2.2\%). $\mathrm{N}$ concentration in Scleroderma ectomycorrhizae varied from $2.8 \%-3.0 \%$ and did not differ between the studied soil horizons. The mean concentration of carbon in Xerocomus ectomycorrhizae varied from $29 \%-46 \%$ in Scots pine stands and from $41 \%-44 \%$ in Scleroderma ectomycorrhizae in sessile oak stands. The concentration of carbon in both Xerocomus and Scleroderma ectomycorrhizae was significantly higher in the fertile horizons (organic and uppermost mineral) compared to the brunic (infertile) horizon. In summary, the analysis conducted in the present study indicates that the LDET ectomycorrhizae, Xerocomus and Scleroderma, possess inherent variations in $\mathrm{C}$ and $\mathrm{N}$ content to manage soil resources.
\end{abstract}

Keywords: Ectomycorrhiza, Soil Interaction, Soil Nitrogen, Nitrogen Utilization, Ectomycorrhizal Adaptation, Soil Chemistry

\begin{abstract}
Introduction
Contact, short-, medium-, long-distance-, and mat-forming-exploration types of ectomycorrhizae can be distinguished based on their morphology and the biomass of emanating hyphae and rhizomorphs (Agerer 2001, 2006). Each of the exploration types may be characterized by a distinct foraging strategy, however, the variation that exists
\end{abstract}

within exploration types and its function under field conditions is poorly understood. Trees have evolved a variety of nutrient-foraging strategies that include variation in root functional traits, as well as an investment in hosting specific ectomycorrhizae (Chen et al. 2013, 2016, 2018). Whether spatial partitioning occurs in the functioning within a single long-distance
(1) Department of Plant Ecology and Environmental Protection, Faculty of Biology, Adam Mickiewicz University, Uniwersytetu Poznanskiego 6, 61-614 Poznan (Poland); (2) Department of Silviculture, Faculty of Forestry and Wood Technology, Poznan University of Life Sciences, Wojska Polskiego 71E, 60-625 Poznan (Poland); (3) Department of Analytical and Environmen tal Chemistry, Faculty of Chemistry, Adam Mickiewicz University, Uniwersytetu Poznanskiego 8, 61-614 Poznan (Poland); (4) Institute of Dendrology, Polish Academy of Sciences, Parkowa 5, 62-035 Kórnik (Poland)

@ Lidia K Trocha (lidia.trocha@amu.edu.pl)

Received: Jul 21, 2020 - Accepted: Nov 08, 2020

Citation: Trocha LK, Bulaj B, Durska A, Frankowski M, Mucha J (2021). Not all long-distanceexploration types of ectomycorrhizae are the same: differential accumulation of nitrogen and carbon in Scleroderma and Xerocomus in response to variations in soil fertility. iForest 14: 48-52. - doi: 10.3832/ifor3594-013 [online 2021-01-18]

Communicated by: Daniela Baldantoni ectomycorrhizal exploration type (LDET) along a substrate-resource gradient, however, has not been determined.

Ectomycorrhizal exploration-types differ in their ability to utilize resources and how they explore soils determines their efficiency (Kuyper \& Landeweert 2002, Baier et al. 2006, Ostonen et al. 2011). Species with extensive mycelia have been reported to be very efficient in nitrogen uptake and sequestration (Kottke et al. 1998, Read \& Perez-Moreno 2003, Hobbie \& Agerer 2010). Thus, fungal exploration strategies can affect tree nutrition (Van Der Heijden \& Kuyper 2003, Courty et al. 2010) due to their differential accumulation and utilization of C and N (Trocha et al. 2010).

Nitrogen levels in fine roots are controlled by carbohydrate fluxes emanating from the host tree (Saravesi et al. 2008, Pena et al. 2010, Trocha et al. 2016), but ectomycorrhizal fungi also differ in the level of $\mathrm{N}$ they provide to their hosts (Hobbie \& Colpaert 2003). The relationship between soil $\mathrm{N}$ availability and $\mathrm{N}$ content in ectomycorrhizae has been characterized under controlled conditions (Högberg et al. 2006, 2011). How ectomycorrhizae within a specific exploration type employ resources from soils that differ in their fertility in a 
natural forest environment, however, has not been examined.

In the present study, the long-distance ectomycorrhizae, Xerocomus and Scleroderma, were used to examine LDET ectomycorrhizae in hosts with contrasting life strategies: pioneer Scots pine (Pinus sylvestris $\mathrm{L}$ ) and mid-successional sessile oak (Quercus petraea Liebl.). These tree species also vary in their nutritional requirements. Scots pine can grow in infertile and dry soils (Przybylski 1993), while sessile oak generally prefers more fertile soils (Fober 2006). Their root systems also differ, while sessile oak quickly forms a taproot capable of reaching deep soil depths and levels of ground water (Lyr \& Hoffman 1967), the root system of Scots pine is fibrous and extensive, and their depth of rooting is not as great as in sessile oak (Roberts 1976).

We previously reported that root function is the most significant driver defining levels of root $\mathrm{N}$ in a specific soil type, however, we also reported a significant decrease in the concentration of soil and root $\mathrm{N}$ in infertile soil layers (Trocha et al. 2017). Notably, the concentration of $\mathrm{N}$ in first-order roots was up to 20-fold higher than it was in the soil layer in which the roots were growing. This finding indicates that there is a strong need to provide roots with nitrogen irrespective of the $\mathrm{N}$ levels present in the surrounding soil environment. In the present study, $\mathrm{N}$ and $\mathrm{C}$ concentrations in LDET ectomycorrhizae were assessed to better determine the presence of natural variation in response to soil resources. LDET ectomycorrhizae, among all exploration types, have been reported to be the most efficient in nutrient foraging; however, there is a high cost for the hostplant to provide LDET ectomycorrhizae with C (Kottke et al. 1998, Read \& PerezMoreno 2003, Hobbie \& Agerer 2010). We hypothesized that $\mathrm{N}$ and $\mathrm{C}$ concentrations in the LDET ectomycorrhizae, Xerocomus and Scleroderma, would not be affected by the fertility of the soil layer: the nutrient concentration in the ectomycorrhizae will be independent from soil nutrient level. We did not aim to discover the exact mechanism for this observation in the current study, but it possibly can be obtainable by some internal mechanism in the ectomycorrhizae (either plant or fungal) regulating the level of nutrient acquisition from the surrounding soil.

\section{Materials and methods}

\section{Study site and roots collection}

Soil samples were collected in September/October 2013 and 2019 from 90-100year-old monoculture stands of sessile oak and Scots pine, located in the Zielonka Forest ( $\left.52^{\circ} 33^{\prime} \mathrm{N}, 17^{\circ} 06^{\prime} \mathrm{E}\right)$, in west-central Poland. The two stands have been managed throughout their entire lifespan according to standards and policies obligatory for State Forests National Forest Holdings. This includes management practices such as cleaning and thinning. Forest management plans in Poland are designed to cover a 10-year period and are prepared by the Bureau of Forest Management and Geodesy (https://www.lasy.gov.pl/en/ourwork/forest-management). The two stands were designated as research sites when the trees had reached maturity. All management operations are synchronized with research activities.

The forest site type for both stands has been classified as a fresh mixed broadleaved forest. The classification of the site conditions is based on the Polish forest typology system which utilizes distinctive features of the soil, forest floor, and stand. The two forest sites used in the study had similar soil, climate, and terrain conditions. Their productivity and utility in silviculture was also similar.

The stands were in a close vicinity (about $100 \mathrm{~m}$ ) to each other and share the same soil type, i.e., rusty soils belonging to Arenosols (Kabala et al. 2016). The tree basal area in the oak stand was 35, and 40 $\mathrm{m}^{2}$ ha $^{-1}$ in the Scots pine stand (measured in 2015). The forest floor consisted mainly of Vaccinium myrtillus, Dryopteris filix-mas and Pleurozium schreberi in the Scots pine stand, and Carex digitata and Dryopteris filix-mas in the sessile oak stand. The undergrowth in the Scots pine stand was dense and completely covered the forest floor, while it was scattered in the oak stand with many bare-soil patches. The climate in this part of Poland is transitional between maritime and continental, with an average annual precipitation of $531 \mathrm{~mm}$ and a mean annual temperature of $8.5^{\circ} \mathrm{C}$.

Three soil pits, $\sim 1 \times 2 \times 2 \mathrm{~m}(\mathrm{~W} \times \mathrm{L} \times \mathrm{D})$ were dug up at the distance of 1-2 $\mathrm{m}$ from the trees to visually characterize the soil horizons. Soil horizons in the soil pits were designated as: organic (O), uppermost mineral $(\mathrm{A})$, brunic (Bbr), illuvial (Bv), and bedrock (C). Soil samples were collected from each horizon (a total of $0.5 \mathrm{~kg}$ ) in each pit for the analysis of soil texture and chemistry. Soil analyses were conducted by the Forest Management and Geodesy Agency in Poznan, Poland (Trocha et al. 2017).

Root samples were simultaneously sampled from all pits. Each pit was surrounded by a few trees and the roots were collected from different sides of the pit, so roots encircled trees adjacent to soil pits, which resulted in a natural heterogeneity. Intact roots were collected from individual soil horizons and preliminarily separated from the soil by hand. Once collected, the roots were washed over sieves (pore size $1 \mathrm{~mm}$ ) under tap water and cleaned with tweezers in a Petri dish to remove attached organic and mineral particles.

Healthy looking ectomycorrhizae were initially evaluated under a stereomicroscope (Olympus GmbH, Düsseldorf, Germany) and organized into morphological groups (morphotypes) based on macroscopic characteristics. Different morpho- types were then classified to the genus or species level based on ITS-barcoding (data not shown; see Fig.S3 in Trocha et al. 2017 for the results). A total of 52 root tips of Scleroderma and 23 root tips of Xerocomus morphotypes were used for molecular identification. Briefly, total genomic DNA was extracted from individual root tips possessing specific morphotypes using a NucleoSpin ${ }^{\oplus}$ Plant II kit (Macherey-Nagel GmbH \& Co., Düren, Germany). The ITS15.8S-ITS2 region was amplified using a fungal-specific ITS1-F primer (Gardes \& Bruns 1993) and a universal ITS4 reverse primer (White et al. 1990). PCR products were purified and sequenced according to the manufacturer's directions using a BigDye Terminator $^{\circledast}$ V3.1 kit and an ABI Prism ${ }^{\oplus} 3130 x \mathrm{xl}$ Genetic Analyzer (Applied Biosystems, USA). Sequence chromatographs were checked for accuracy in Chromas LITE v.2.01 (http:// www.techenysium.com.au) and aligned by the CodonCode Aligner (http://www.codon code.com/aligner/) using a $\geq 97 \%$ identity threshold to group ectomycorrhizal sequences into operational taxonomic units (OTUs), which were subsequently used to query sequences in GenBank (https:// blast.ncbi.nlm.nih.gov/blast.cgi) and UNITE (https://unite.ut.ee) databases. Sequences representing each OTU, including Xerocomus and Scleroderma, were deposited in GenBank under accession numbers KP731808-64.

After all of the collected ectomycorrhizal morphotypes were identified at the molecular level, ectomycorrhizal roots of Xerocomus in Scots pine and Scleroderma in sessile oak were specifically collected from the soil horizons of interest and used for $\mathrm{C}$ and $\mathrm{N}$ analyses. Molecular identification was not explicitly applied for these ectomycorrhizae as the samples were dried prior to $C$ and $\mathrm{N}$ analyses.

\section{Total nitrogen and carbon concentrations}

Samples (approximately $500 \mathrm{mg}$ ) of fresh Xerocomus and Scleroderma ectomycorrhizal roots were collected from the soil horizons of interest in September 2013 and 2019. Depending on the size of ectomycorrhizae, samples comprised ca. 10 to $30 \mathrm{ECM}$ root tips that were obtained from different root branches (to avoid root homogeneity). In total, 54 samples of Xerocomus and 70 samples of Scleroderma were analyzed. Samples were oven-dried $\left(65^{\circ} \mathrm{C}\right.$ for $48 \mathrm{~h}$ ), ground, and subsequently analyzed for total $\mathrm{N}$ and $\mathrm{C}$ with an elemental analyzer (model CHNS-O 4010, Costech Instruments, Italy/USA).

\section{Data analysis}

Two-way analysis of variance was used to determine the effect of soil horizon and year of harvest on levels of nitrogen (N\%) and carbon (C\%), and C: $\mathrm{N}$ ratios in ectomycorrhizae. The data on Xerocomus and Scleroderma ectomycorrhizae were analyzed separately. Due to a lack of normal distribu- 
Tab. 1 - Mean ( \pm standard error) abundance (\%) of species of Scleroderma and Xerocomus ectomycorrhizae in the studied soil horizons. Means were calculated from the total number of ectomycorrhizal root tips collected in each horizon $(n=3)$. (a): Scleroderma bovista and Xerocomus cisalpinus were not found in the studied soil horizons, but were found in the other soil horizons (illuvial and bedrock).

\begin{tabular}{lccccccc}
\hline \multirow{2}{*}{ Soil horizon } & \multicolumn{2}{c}{ Quercus petraea } & \multicolumn{5}{c}{ Pinus sylvestris } \\
\cline { 2 - 8 } & $\begin{array}{c}\text { Scleroderma } \\
\text { areolatum }\end{array}$ & S. bovista & S. citrinum & S. verrucosum & $\begin{array}{c}\text { Xerocomus } \\
\text { badius }\end{array}$ & X. cisalpinus $^{\mathrm{a}}$ & $X_{\text {X. ferrugineus }}$ \\
\hline Organic (O) & $7.0 \pm 4.0$ & 0.0 & $4.0 \pm 3.6$ & 0.0 & $51 \pm 22$ & 0.0 & 0.0 \\
\hline Mineral (A) & $0.8 \pm 0.8$ & 0.0 & $3.0 \pm 2.0$ & 0.0 & $43 \pm 28$ & 0.0 & 0.0 \\
\hline Brunic (Bbr) & $1.4 \pm 0.2$ & 0.0 & $4.0 \pm 2.7$ & $22.0 \pm 22.0$ & 0.0 & 0.0 & $34 \pm 4$ \\
\hline
\end{tabular}

tion, data were log-transformed prior to analysis. Post-hoc Tukey-Kramer HSD comparisons were performed for all pairs. The analyses were performed in $\mathrm{JMP}^{\otimes}$ v.8.0 (SAS Institute Inc., Cary, NC, USA).

\section{Results}

\section{Soil structure and chemistry}

The soil chemical and structural parameters for each of the horizons in the soil pits were measured (Trocha et al. 2017). The organic horizon in both sessile oak and Scots pine soil pits had the highest mineral status, exchange cations, and soil porosity, while low mineral concentrations, high density, base saturation, and $\mathrm{pH}$ were characteristic of the brunic horizon in both forest stands.

\section{Molecular analysis}

Analysis of the ITS data indicated that the Scleroderma and Xerocomus morphotypes were composed of four and three species, respectively. Three species of Scleroderma (S. areolatum, S. citrinum, and S. verrucosum) were detected in the studied soil horizons (Tab. 1). S. citrinum dominated in the organic horizon, S. areolatum in the uppermost mineral, and S. verrucosum in the brunic horizon. Xerocomus badius was abundant in all three of the studied soil horizons, while $X$. ferrugineus was only present in low abundance in the brunic horizon.

\section{Concentrations of total nitrogen and carbon in the ectomycorrhizae}

Mean nitrogen concentrations in Xerocomus ectomycorrhizae ranged from $2.2 \%$ $3.4 \%$ and from $2.8 \%-3.0 \%$ in Scleroderma ectomycorrhizae across all of the studied soil horizons (Tab. 2). The mean concentration of carbon in Xerocomus ectomycorrhizae ranged from $29 \%-46 \%$ and from $41 \%-44 \%$ in Scleroderma ectomycorrhizae across all of the studied soil horizons. Xerocomus ectomycorrhizae had a higher concentration of $\mathrm{N}(3.4 \%)$ in the fertile soil horizons (i.e., organic and uppermost mineral soil horizons) than in the infertile (brunic) soil horizon (2.2\%). The concentration of $\mathrm{N}$ in Scleroderma ectomycorrhizae did not vary in the studied soil horizons. The concentration of carbon in both Xerocomus and Scleroderma ectomycorrhizae was significantly higher in the fertile horizons, relative to the brunic horizon. Surprisingly, the mean concentration of $C$ was as low as $29 \%$ in Xerocomus ectomycorrhizae growing in the brunic horizon. Overall, the mean concentrations of $\mathrm{N}$ and $\mathrm{C}$ in Xerocomus were higher in ectomycorrhizae collected in 2019 than in those collected in 2013 (Tab. 3). In contrast, the concentration of carbon was higher in Scleroderma ectomycorrhizae collected in 2013 than in those collected in 2019, while no differences in mean carbon levels were observed for Xerocomus (data not shown).

The $\mathrm{C} / \mathrm{N}$ ratio of Xerocomus ectomycorrhizae did not vary among the soil horizons in Scots pine (Tab. 2, Tab. 3). The $\mathrm{C} / \mathrm{N}$ ratio, however, was lower in Scleroderma ectomycorrhizae growing in the brunic (infertile) horizon of the sessile oak stand, relative to the Scleroderma ectomycorrhizae growing in the organic horizon.

\section{Discussion}

Contrary to our hypothesis, LDET ectomycorrhizae possess natural variations in $\mathrm{N}$ mobilization and/or uptake (expressed as $\mathrm{N}$ concentration) in response to soil fertility. As shown, Scleroderma is capable of absorbing $\mathrm{N}$ in infertile soil layers comparable to the $\mathrm{N}$ it absorbs in fertile soil horizons, while Xerocomus depends mostly on the fertile soil layer to obtain its N. It should be noted, however, that the Scleroderma and Xerocomus samples analyzed in our study may have contained more than one EMF species, which may also explain the interhorizons variations that were observed. Although LDET ectomycorrhizae with higher mycelial biomass are more enriched in ${ }^{55} \mathrm{~N}$

Tab. 2 - Mean ( \pm standard error) carbon (C) and nitrogen ( $N$ ) concentration (\%) and the $\mathrm{C} / \mathrm{N}$ ratio in Xerocomus and Scleroderma ectomycorrhizae collected in the studied soil horizons: organic $(\mathrm{O})$, uppermost mineral $(\mathrm{A})$, and brunic (Bbr) across soil vertical profiles in Pinus sylvestris and Quercus petrea stands in the Zielonka Forest, west-central Poland. Means with different letters are significantly different.

\begin{tabular}{lllccc}
\hline EMF & Horizon & $\boldsymbol{n}$ & $\mathrm{C} \%$ & $\mathrm{~N} \%$ & $\mathrm{C} / \mathrm{N}$ \\
\hline Xerocomus & $\mathrm{O}$ & 22 & $46 \pm 0.2^{\mathrm{a}}$ & $3.4 \pm 0.1^{\mathrm{a}}$ & 14 \\
\cline { 2 - 6 } & $\mathrm{A}$ & 18 & $45 \pm 0.3^{\mathrm{a}}$ & $3.4 \pm 0.1^{\mathrm{a}}$ & 14 \\
\cline { 2 - 6 } Scleroderma & $\mathrm{Bbr}$ & 14 & $29 \pm 2.0^{\mathrm{b}}$ & $2.2 \pm 0.1^{\mathrm{b}}$ & 13 \\
& $\mathrm{O}$ & 32 & $44 \pm 0.7^{\mathrm{a}}$ & $2.8 \pm 0.1$ & $16^{\mathrm{ab}}$ \\
\cline { 2 - 6 } & $\mathrm{A}$ & 19 & $43 \pm 0.5^{\mathrm{a}}$ & $2.8 \pm 0.1$ & $16^{\mathrm{a}}$ \\
\cline { 2 - 6 } & $\mathrm{Bbr}$ & 19 & $41 \pm 0.9^{\mathrm{b}}$ & $3.0 \pm 0.1$ & $14^{\mathrm{b}}$ \\
\hline
\end{tabular}

Tab. 3 - ANOVA of the effect of soil horizon (organic, uppermost mineral, and brunic) and harvest year (2013 and 2019) on the concentration of nitrogen and carbon and C/ $\mathrm{N}$ ratio in Scleroderma and Xerocomus ectomycorrhizae collected in the studied soil horizons

\begin{tabular}{|c|c|c|c|c|c|c|c|}
\hline \multirow{3}{*}{ EMF } & \multirow{3}{*}{$\begin{array}{l}\text { Dependent } \\
\text { variables }\end{array}$} & \multicolumn{6}{|c|}{ Independent variables } \\
\hline & & \multicolumn{2}{|c|}{ Soil horizon $(\mathrm{H})$} & \multicolumn{2}{|c|}{ Harvest year $(\mathrm{Y})$} & \multicolumn{2}{|c|}{$\mathrm{H} \times \mathrm{Y}$} \\
\hline & & $F$ & Prob & $F$ & Prob & $F$ & Prob \\
\hline \multirow{3}{*}{ 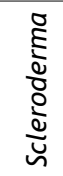 } & Nitrogen $(\%)$ & 0.8 & 0.5 & 1.3 & 0.3 & 0.9 & 0.4 \\
\hline & Carbon (\%) & 0.001 & $<0.0001$ & 23 & $<0.0001$ & 5.2 & 0.008 \\
\hline & $\mathrm{C} / \mathrm{N}$ & 3.8 & 0.03 & 10 & 0.002 & 0.1 & 0.9 \\
\hline \multirow{3}{*}{ 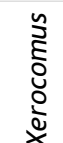 } & Nitrogen $(\%)$ & 4.1 & 0.05 & 43 & $<0.0001$ & 14 & $<0.0001$ \\
\hline & Carbon (\%) & 69 & $<0.0001$ & 13 & 0.0008 & 18 & $<0.0001$ \\
\hline & $\mathrm{C} / \mathrm{N}$ & 0.5 & 0.6 & 2.6 & 0.1 & 0.3 & 0.8 \\
\hline
\end{tabular}


than those with lower mycelial biomass (Hobbie \& Agerer 2010), suggesting the existence of a fungal strategy for nitrogen ac quisition that supports biomass accumulation, specific species of ectomycorrhizal fungi may be able to utilize nutrients from a broad range of soil resources using a variety of different processes including enzymes (Courty et al. 2010). Alterations in N and $C$ levels in LDET ectomycorrhizae may also be a function, however, of varying levels of nutrients in the different nutrient pools being accessed by the fungi (Pena et al. 2017).

Forest soils possess diverse sources of nitrogen, mainly as a result of litter decomposition, including labile amino acids, amino sugars, nucleotides, and complex molecules like chitin and polypeptides (Courty et al. 2010). ECM fungi are capable of utilizing complex molecules through the secretion of proteases (Nygren et al. 2007, Talbot et al. 2013) whose production can be inhibited by various soil factors, including high amounts of inorganic $\mathrm{N}$ (Lilleskov et al. 2002). Inter- and intraspecific variation in the capacity to synthesize proteolytic enzymes (Nygren et al. 2007, Courty et al. 2010), as well as sensitivity to inorganic $\mathrm{N}$ loads (Lilleskov et al. 2011), have also been reported to provide the opportunity for ECM fungi to differentially utilize $\mathrm{N}$ sources. Utilization of diverse $\mathrm{N}$ sources also varies among ECM exploration types (Lilleskov et al. 2002), especially in those that form a hydrophobic medium-distance fringe exploration type, which are strongly sensitive to inorganic $\mathrm{N}$ deposition (Lilleskov et al. 2011). In contrast, hydrophilic exploration types, including contact, shortdistance, and medium-distance types of ectomycorrhizae, respond positively or exhibit a mixed response to $\mathrm{N}$ inorganic deposition. This is most likely due to a lower investment in their extramatrical hyphae (Lilleskov et al. 2011). These authors also indicated that the variable response of hydrophobic long-distance exploration type fungi to inorganic $\mathrm{N}$ loads suggests that $\mathrm{C}$ allocation in this exploration type (which probably requires high amounts of $\mathrm{C}$ from their host) is not limited to inorganic N-sensitive taxa alone (Lilleskov et al. 2011). In this regard, the response of Xerocomus and Scleroderma to soil fertility can be understood as interspecific variability in their preferences to $\mathrm{N}$ sources. Xerocomus may need to obtain $\mathrm{N}$ from soil organic matter decomposition (high $\mathrm{N}$ and $\mathrm{C}$ in fertile soil horizons), while Scleroderma can also utilize labile $\mathrm{N}$ compounds that are mostly in infertile soil horizons, possibly also via the weathering of minerals (Landeweert et al. 2001). To further explore this question, another study on diverse LDET ectomycorrhizae in relation with diverse forms of nitrogen (inorganic vs. organic) could be applied.

Ectomycorrhizal fungi are highly dependent on receiving carbon from their host (Nehls et al. 2010, Teramoto et al. 2016), even though some have some capacity to utilize carbon from soil organic matter (Hobbie et al. 2014, Lindahl \& Tunlid 2015). It has been proposed that the high carbon cost associated with ectomycorrhizal fungi is due to their high nutrient uptake (Bogar et al. 2019), which varies among ectomycorrhizal fungal species, as they differ in carbon sink strength (Bidartondo et al. 2001, Pena et al. 2010). It is also believed that long-distance-exploration type ectomycorrhizae are more effective in nutrient acquisition than other ectomycorrhizal exploration-types due to the extensive hyphae that they protrude out from the root surface. This mycelial extension is used to explore the surrounding soil for nutrients. The ability to acquire nutrients, however, can vary considerably between different species LDET ectomycorrhizae, independent of the biomass of mycelia produced (Bidartondo et al. 2001, Taylor et al. 2003). Ectomycorrhizal species of fungi also utilize different nitrogen sources with varying degrees of efficiency (Finlay et al. 1992), suggesting that nitrogen source may ( $\mathrm{Bi}$ dartondo et al. 2001) or may not (Taylor et al. 2003) impact the amount of carbon transferred to the ectomycorrhizal fungus. Ectomycorrhizal fungi can also retain and store nitrogen when $\mathrm{N}$ in the soil is limited (Hobbie \& Agerer 2010, Högberg et al. 2011). Trees also allocate less carbon to ectomycorrhizal fungi when nitrogen levels are in excess (Högberg et al. 2006, Morrison et al. 2016); suggesting that the level of soil $\mathrm{N}$ is a key factor regulating the function of ectomycorrhizae. Tedersoo et al. (2012) reported a strong effect of ectomycorrhizal fungal lineage, rather than ectomycorrhizal exploration-type, on measured levels of stable nitrogen $\left({ }^{15} \mathrm{~N}\right)$. Although the level of enzymes in long-distance ectomycorrhizal exploration-types has been reported to be higher than in other exploration types (Tedersoo et al. 2012), we suggest that an unknown mechanism may allow Scleroderma in sessile oak stands to acquire similar amounts of nitrogen in unfertile soil horizons as it does in more fertile soil horizons (e.g., organic layer). Whether the mechanism is related enzyme production, mineral weathering, or specific interactions among ECM fungi, is unknown. Additional experiment could help to explain the extent to which LDET ectomycorrhizae are capable of using natural $\mathrm{N}$ sources from a specific soil as well as the cost to the host for this investment.

Long-distance-exploration type ectomycorrhizae have been suggested to be best adapted to infertile soils, but variation within this exploration type exists. While $\mathrm{N}$ and $\mathrm{C}$ concentrations in Xerocomus were lowered significantly with a decrease in soil fertility along a soil vertical profile in a Scots pine stand, $\mathrm{N}$ and $\mathrm{C}$ concentrations in Scleroderma in a sessile oak stand were for the most part unaffected. This finding suggests that not all LDET ectomycorrhizae exhibit the same response to soil fertility.

\section{Acknowledgments}

LKT and $B B$ designed the experiment, $L K T, B B, A D$, and JM collected the samples; LKT, AD, MF and JM analyzed the samples, LKT and AD analyzed data; LKT wrote the first version of the manuscript. All authors contributed to manuscript revisions.

This research was supported by a grant (2011/01/D/NZ8/01760) funded by the National Science Centre (Poland) to Lidia K. Trocha and the Institute of Dendrology of the Polish Academy of Sciences in Kórnik, Poland. The authors are grateful to Dr. Pawel Rutkowski for his support during soil analyses and root collection, Elzbieta Rudy for her help in the molecular analyses of ectomycorrhizal roots, and the employees of the Forest Experimental Station Murowana Goslina for information pertaining to the study site. The authors are also thankful to Dr. Dale Karlson for his irreplaceable advice in language correction and text edit.

The authors declare that they have no conflict of interest.

\section{References}

Agerer R (2001). Exploration types of ectomycorrhizae. A proposal to classify ectomycorrhizal mycelia systems according to their patterns of differentiation and putative ecological importance. Mycorrhiza 11: 107-114. - doi: 10.1007/s005 720100108

Agerer R (2006). Fungal relationships and structural identity of their ectomycorrhizae. Mycological Progress 5: 67-107. - doi: 10.1007/s11557-0 06-0505-x

Baier R, Ingenhaag J, Blaschke $H$, Göttlein A, Agerer R (2006). Vertical distribution of an ectomycorrhizal community in upper soil horizons of a young Norway spruce (Picea abies [L.] Karst.) stand of the Bavarian Limestone Alps. Mycorrhiza 16: 197-206. - doi: 10.1007/s00572006-0035-z

Bidartondo MI, Ek H, Wallander H, Söderström B (2001). Do nutrient additions alter carbon sink strength of ectomycorrhizal fungi? New Phytologist 151: 543-550. - doi: 10.1046/j.1469-8137.200 1.00180.x

Bogar L, Peay K, Kornfeld A, Huggins J, Hortal S, Anderson I, Kennedy P (2019). Plant-mediated partner discrimination in ectomycorrhizal mutualisms. Mycorrhiza 29: 97-111. - doi: 10.1007/so 0572-018-00879-7

Chen W, Zeng H, Eissenstat DM, Dali Guo D (2013). Variation of first-order root traits across climatic gradients and evolutionary trends in geological time. Global Ecology and Biogeography 22: 846-856. - doi: 10.1111/geb.12048

Chen W, Koide RT, Adams TS, DeForest JL, Cheng L, Eissenstat DM (2016). Root morphology and mycorrhizal symbioses together shape nutrient foraging strategies of temperate trees. Proceedings of the National Academy of Sciences USA 113: 8741-8746. - doi: 10.1073/ pnas.1601006113

Chen W, Eissenstat DM, Koide RT (2018). Root diameter predicts the extramatrical hyphal exploration distance of the ectomycorrhizal fungal community. Ecosphere 9 (4): e02202. - doi: 10.1002/ecs2.2202

Courty P-E, Buée M, Diedhiou AG, Frey-Klett P, 
Le Tacon F, Rineau F, Turpault M-P, Uroz S, Garbaye $J$ (2010). The role of ectomycorrhizal communities in forest ecosystem processes: New perspectives and emerging concepts. Soil Biology and Biochemistry 42: 679-698. - doi: 10.101 6/j.soilbio.2009.12.006

Finlay RD, Frostegård A, Sonnerfeldt A-M (1992). Utilization of organic and inorganic nitrogen sources by ectomycorrhizal fungi in pure culture and in symbiosis with Pinus contorta Dougl. ex Loud. New Phytologist 120: 105-115. doi: 10.1111/j.1469-8137.1992.tb01063.x

Fober H (2006). Odzywianie mineralne. w: "Nasze drzewa lesne- Deby" [Mineral nutrition. In: "Tree species of Poland - Oaks"] (Boratynski A, Bugala W eds). Bogucki Wydawnictwo Naukowe, Kórnik, Poznan, Poland, pp. 232-264. [in Polish]

Gardes M, Bruns TD (1993). ITS primers with enhanced specificity for basidiomycetes - Application to the identification of mycorrhizae and rusts. Molecular Ecology 2: 113-118. - doi: 10.1111/ j.1365-294X.1993.tbooo05.x

Hobbie EA, Agerer R (2010). Nitrogen isotopes in ectomycorrhizal sporocarps correspond to belowground exploration types. Plant and Soil 327: 71-83. - doi: 10.1007/s11104-009-0032-z

Hobbie EA, Colpaert JV (2003). Nitrogen availability and colonization by mycorrhizal fungi correlate with nitrogen isotope patterns in plants. New Phytologist 157: 115-126. - doi: 10.1046/j.1469-8137.2003.00657.x

Hobbie EA, Hofmockel KS, Van Diepen LTA, Lilleskov EA, Ouimette AP, Finzi AC (2014). Fungal carbon sources in a pine forest: evidence from a ${ }^{13} \mathrm{C}$-labeled global change experiment. Fungal Ecology 10: 91-100. - doi: 10.1016/j.fun eco.2013.11.001

Högberg MN, Myrold DD, Giesler R, Högberg P (2006). Contrasting patterns of soil $\mathrm{N}$ cycling in model ecosystems of Fennoscandian boreal forests. Oecologia 147: 96-107. - doi: 10.1007/so 0442-005-0253-7

Högberg P, Johannisson C, Yarwood S, Callesen I, Näsholm T, Myrold DD, Högberg MN (2011). Recovery of ectomycorrhiza after "nitrogen saturation" of a conifer forest. New Phytologist 189: 515-525. - doi: 10.1111/j.1469-8137.2010. 03485.x

Kabala C, Switoniak M, Charzynski P (2016). Correlation between the Polish Soil Classification (2011) and international soil classification system World Reference Base for Soil Resources (2015). Soil Science Annual 67: 88-100. - doi: 10.1515/ssa-2016-0012

Kottke I, Qian XM, Pritsch K, Haug I, Oberwinkler F (1998). Xerocomus badius - Picea abies, an ectomycorrhiza of high activity and element storage capacity in acidic soil. Mycorrhiza 7: 267275. - doi: 10.1007/s005720050191

Kuyper TW, Landeweert R (2002). Vertical niche differentiation by hyphae of ectomycorrhizal fungi in soil. New Phytologist 156: 323-325. - doi: 10.1046/j.1469-8137.2002.00548.x

Landeweert R, Hoffland E, Finlay RD, Kuyper TW, Van Breemen N (2001). Linking plants to rocks: ectomycorrhizal fungi mobilize nutrients from minerals. Trends in Ecology and Evolution 16: 248-254. - doi: 10.1016/S0169-5347(01)02122-X

Lilleskov EA, Hobbie EA, Fahey TJ (2002). Ectomycorrhizal fungal taxa differing in response to nitrogen deposition also differ in pure culture organic nitrogen use and natural abundance of nitrogen isotopes. New Phytologist 154: 219231. - doi: 10.1046/j.1469-8137.2002.00367.x Lilleskov EA, Hobbie EA, Horton TR (2011). Conservation of ectomycorrhizal fungi: exploring the linkages between functional and taxonomic responses to anthropogenic $\mathrm{N}$ deposition. Fungal Ecology 4: 174-183. - doi: 10.1016/j. funec0.2010.09.008

Lindahl BD, Tunlid A (2015). Ectomycorrhizal fungi - potential organic matter decomposers, yet not saprotrophs. New Phytologist 205: 1443-1447. - doi: 10.1111/nph.13201

Lyr H, Hoffman G (1967). Growth rates and growth periodicity of tree roots. International Review of Forest Research 2: 181-236. - doi: 10.1016/B978-1-4831-9976-4.50011-X

Morrison EW, Frey SD, Sadowsky JJ, Van Diepen LTA, Thomas WK, Pringle A (2016). Chronic nitrogen additions fundamentally restructure the soil fungal community in a temperate forest. Fungal Ecology 23: 48-57. - doi: 10.1016/j.funeco. 2016.05.011

Nehls U, Göhringer F, Wittulsky S, Dietz S (2010). Fungal carbohydrate support in the ectomycorrhizal symbiosis: a review. Plant Biology 12: 292301. - doi: 10.1111/j.1438-8677.2009.00312.x

Nygren CM, Edqvist J, Elfstrand M, Heller G, Taylor AFS (2007). Detection of extracellular protease activity in different species and genera of ectomycorrhizal fungi. Mycorrhiza 17: 241-248. doi: 10.1007/s00572-006-0100-7

Ostonen I, Helmisaari H-S, Borken W, Tedersoo L, Kukumagi $M$, Bahram $M$, Lindroos A-J, Nojd P, Uri V, Merila P, Asi E, Lohmus K (2011). Fine root foraging strategies in Norway spruce forests across a European climate gradient. Global Change Biology 17: 3620-3632. - doi: 10.1111/j.136 5-2486.2011.02501.x

Pena R, Offermann C, Simon J, Naumann PS, Geßler A, Holst J, Dannenmann M, Mayer H, Kögel Knabner I, Rennenberg H, Polle A (2010). Girdling affects ectomycorrhizal fungal (EMF) diversity and reveals functional differences in EMF community composition in a beech forest. Applied and Environmental Microbiology 76: 1831-1841. - doi: 10.1128/AEM.01703-09

Pena R, Lang C, Lohaus G, Boch S, Schall P, Schöning I, Ammer C, Fischer M, Polle A (2017). Phylogenetic and functional traits of ectomycorrhizal assemblages in top soil from different biogeographic regions and forest types. Mycorrhiza 27: 233-245. - doi: 10.1007/s00572-016-074 2-z

Przybylski T (1993). Biologia sosny zwyczajnej [Biology of Pinus sylvestris] (Bialobok S, Boratynski A, Bugala W eds). Instytut Dendrologii Polskiej Akademii Nauk, Sorus, Poznan-Kórnik, Poland, pp. 264-265. [in Polish]

Read DJ, Perez-Moreno J (2003). Mycorrhizas and nutrient cycling in ecosystems - a journey towards relevance? New Phytologist 157: 475-
492. - doi: 10.1046/j.1469-8137.2003.00704.x Roberts J (1976). A study of root distribution and growth in a Pinus sylvestris L. (Scots pine) plantation in east Anglia. Plant and Soil 44: 607-621. - doi: 10.1007/BFo0011380

Saravesi K, Markkola A, Rautio P, Roitto M, Juha Tuomi J (2008). Defoliation causes parallel temporal responses in a host tree and its fungal symbionts. Oecologia 156: 117-123. - doi: 10.1007/ s00442-008-0967-4

Talbot JM, Bruns TD, Smith DP, Branco S, Glassman SI, Erlandson S, Vilgalys R, Peay KG (2013). Independent roles of ectomycorrhizal and saprotrophic communities in soil organic matter decomposition. Soil Biology and Biochemistry 57: 282-291. - doi: 10.1016/j.soilbio.2012.10.004

Taylor AFS, Fransson PM, Högberg P, Högberg MN, Plamboeck AH (2003). Species level patterns in ${ }^{13} \mathrm{C}$ and ${ }^{15} \mathrm{~N}$ abundance of ectomycorrhizal and saprotrophic fungal sporocarps. New Phytologist 159: 757-774. - doi: 10.1046/j.1469-81 37.2003.00838.x

Tedersoo L, Naadel T, Bahram M, Pritsch K, Buegger F, Leal M, Kõljalg U, Põldmaa K (2012). Enzymatic activities and stable isotope patterns of ectomycorrhizal fungi in relation to phylogeny and exploration types in an afrotropical rain forest. New Phytologist 195: 832-843. - doi: 10.1111/j.1469-8137.2012.04217.x

Teramoto M, Wu B, Hogetsu T (2016). Pathway and sink activity for photosynthate translocation in Pisolithus extraradical mycelium of ectomycorrhizal Pinus thunbergii seedlings. Mycorrhiza 26: 453-464. - doi: 10.1007/s00572-016-068 4-5

Trocha LK, Mucha J, Eissenstat DM, Reich PB, Oleksyn J (2010). Ectomycorrhizal identity determines respiration and concentrations of nitrogen and nonstructural carbohydrates in root tips: a test using Pinus sylvestris and Quercus robur saplings. Tree Physiology 30: 648-654. doi: 10.1093/treephys/tpq014

Trocha LK, Weiser E, Robakowski P (2016). Interactive effects of juvenile defoliation, light conditions, and interspecific competition on growth and ectomycorrhizal colonization of $\mathrm{Fa}$ gus sylvatica and Pinus sylvestris seedlings. Mycorrhiza 26: 47-56. - doi: 10.1007/s00572-015-064 5-4

Trocha LK, Bulaj B, Kutczynska P, Mucha J, Rutkowski P, Zadworny M (2017). The interactive impact of root branch order and soil genetic horizon on root respiration and nitrogen concentration. Tree Physiology 37: 1055-1068. - doi: 10.1093/treephys/tpxo96

Van Der Heijden EW, Kuyper TW (2003). Ecological strategies of ectomycorrhizal fungi of Salix repens: root manipulation versus root replacement. Oikos 103: 668-680. - doi: 10.1034/j.16000706.2003.10638.x

White TJ, Bruns T, Lee S, Taylor J (1990). Amplification and direct sequencing of fungal ribosomal RNA genes for phylogenetics. In: "PCR Protocols: A Guide to Methods and Applications" (Innis DHGMA, Sninsky JJ, White TJ eds). Academic Press, New York, USA, pp. 315-322. - doi: 10.1016/B978-0-12-372180-8.50042-1 